\title{
Dimensões de Performance de Projetos Paisagísticos Contemporâneos na Orla Marítima de Salvador, Bahia
}

\section{Angelo Serpa}

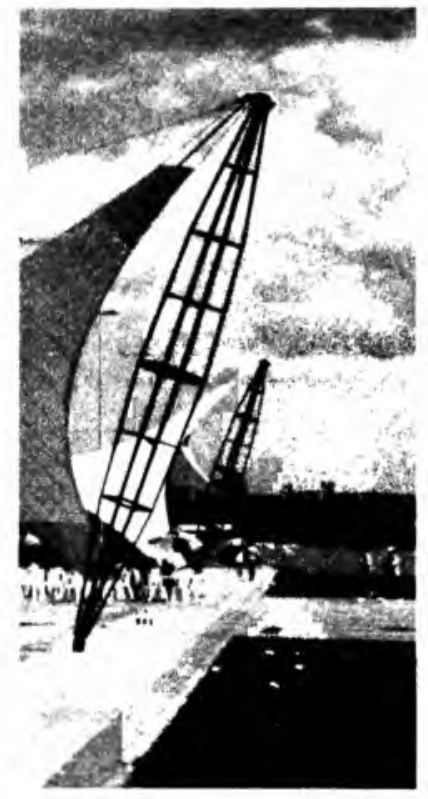

Engenheiro florestal, doutor, professor adjunto do Departamento de Mestrado de Geografia e do programa de pós-graduaçāo em arquitetura e urbanismo da Universidade Federal da Bahia, pesquisador do Conselho Nacional de Desenvolvimento Cientifico e Tecnológico

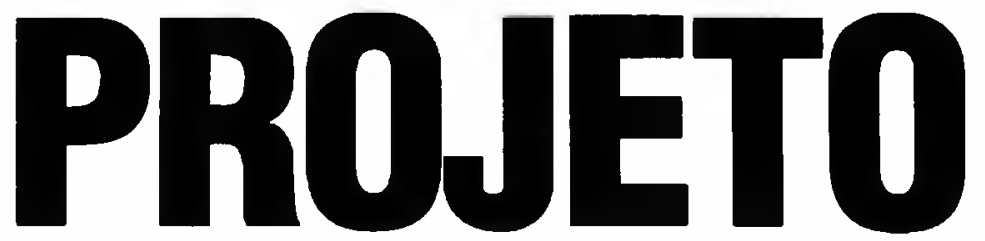


O Parque Costa Azul é um dos mais novos espaços públicos de esporte, cultura e lazer de Salvador. Inaugurado em 1997, é um complexo de 55 mil metros quadrados, que reúne pista de cooper e de patinação, ciclovia, playground com aparelhos de ginástica, além de restaurantes, anfiteatro e estacionamento. Ocupando a área do antigo Clube Costa Azul, na orla de Salvador, é uma alternativa de entretenimento, principalmente para os moradores dos bairros próximos, que nos finais de semana acabavam elegendo a praia como principal opção de lazer. A partir de 1999, a cidade ganhou um trecho da orla maritima totalmente reurbanizado. A área entre o Jardim dos Namorados e o Costa Azul, de $100 \mathrm{mil} \mathrm{m}^{2}$ e com extensão de $1,5 \mathrm{~km}$, recebeu novos equipamentos. $E$ com melhorias nos sistemas viário e de circulação e nova iluminação. Os dois projetos são marcados pela funcionalidade dos subespaços e pela ausẽncia de vegetação de porte, com uma forte presença de elementos construidos e de obras artísticas como painéis e esculturas. Pórticos coloridos e de formas diferenciadas, característicos do paisagismo contemporāneo, estão presentes, denotando a influência de projetos desenvolvidos na Europa e Estados Unidos. Este trabalho discute a tendência à homogeneização da linguagem projetual no paisagismo contemporāneo, em conseqüência da globalização e internacionalização dos projetos paisagísticos, com base no conceito de não-lugar, proposto por autores como Augẽ e Relph. São analisadas - para ambos os projetos - as "dimensões de performance", propostas por Lynch em sua "teoria da boa forma urbana".

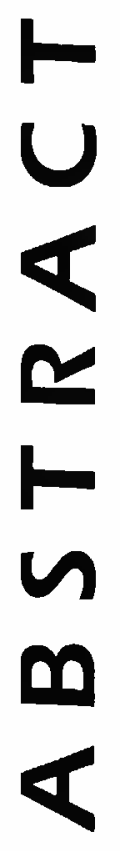

Parque Costa Azul is one of the newest public spaces for sports, culture and leisure in Salvador. Inaugurated on 1997, it is a complex of 55,000 sq. meters, including a jogging track, a skating-rink, a biking track, playground with gym equipment, as well as restaurants, amphitheater and parking. Occupying the old Costa Azul Club, on the outskirts of Salvador, the park is an alternative to entertainment, mainly for the inhabitants of the neighboring areas, who, on weekends, would up choosing the beach as their main leisure option. From 1999, the city received a section of beach property that had been completely refurbished. The area between the Jardim dos Namorados and the Costa Azul, 100,000 sq. meters and $1.5 \mathrm{~km}$ long, received new equipment, and road traffic and lightning improvements. The two projects are characterized by the functionality of the subspaces and the absence of larger vegetation, with much construction on the grounds and artistic workmanships such as boards and sculptures. Colorful porches of differentiated forms, characteristic of contemporary landscaping, are present, demonstrating the influence of designs developed in Europe and United States. This work analyzes the trend towards homogenization of the designing language in the contemporary landscaping, as a consequence of globalization and internationalization of landscaping designs, on the basis of the concept of not-place, proposed by authors such as Auge and Relph. The

"dimensions of performance" are examined - for both the projects - as proposed by Lynch in his "theory of good urban form".

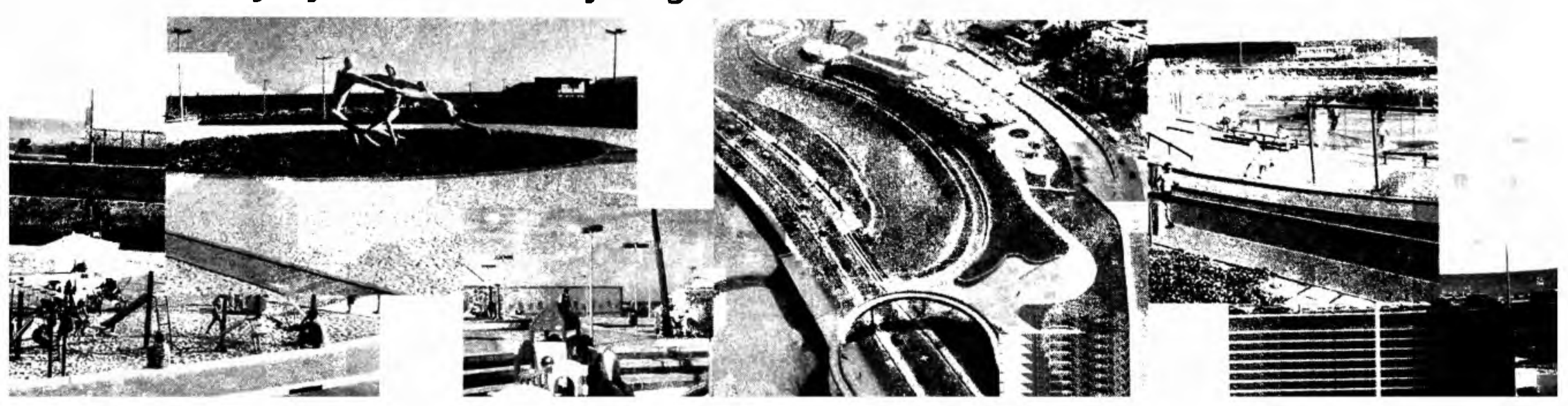




\section{Dimensões de Performance de Projetos Paisagísticos Contemporâneos na Orla Maritima de Salvador, Bahia}

A execução dos projetos paisagísticos na orla marítima de Salvador integra um elenco de ações integradas previstas no Projeto Metropolitano, da Companhia de Desenvolvimento da Região Metropolitana de Salvador (CONDER). Iniciado em 1986, o projeto passou a contar, a partir de 1991, com recursos do governo federal e do Banco Mundial, constituindo-se em um programa de investimentos urbanos, com ações abrangendo os 10 municípios que compõem a Região Metropolitana de Salvador (RMS), desdobradas em cinco linhas básicas: limpeza urbana, saneamento básico, recuperação urbana, assistência técnica ao Centro Histórico e Desenvolvimento Institucional (CONDER, 1998).

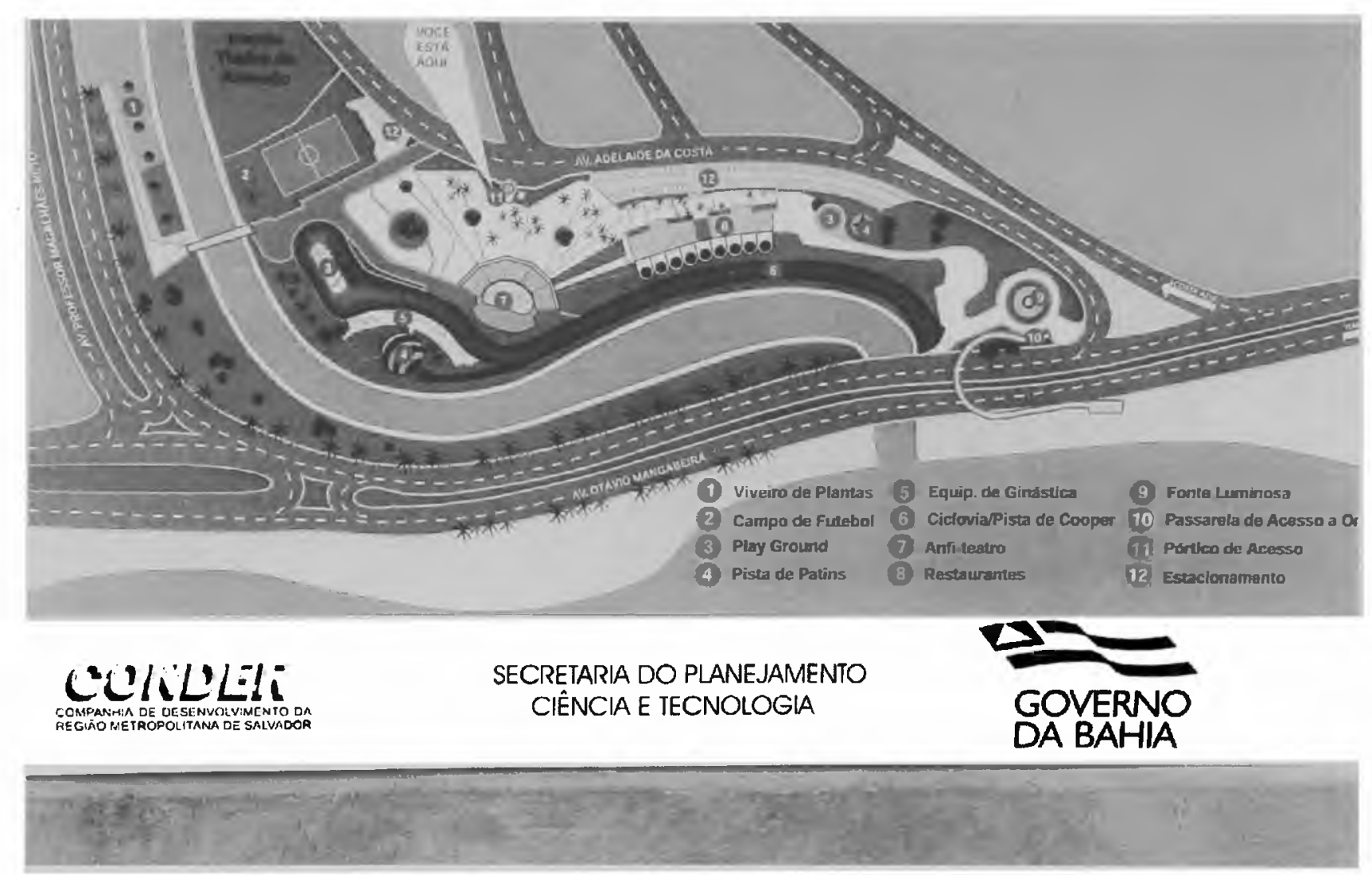

Foto 1: Planta baixa do Parque Costa Azul

Foto: Angelo Serpa

O Parque Costa Azul foi implantado na área das ruínas do antigo Hotel Costa Azul, na orla marítima de Salvador, marcada pelo lançamento de esgotos, acúmulo de detritos e pelo mau cheiro. As obras de implantação do parque realizaram-se concomitantemente aos trabalhos de desvio do rio Camurugipe e seus esgotos, para a rede da EMBASA, por meio da construção de um interceptor. O novo parque (Fotos 1 e 2), com projeto do arquiteto José Tabacow, 


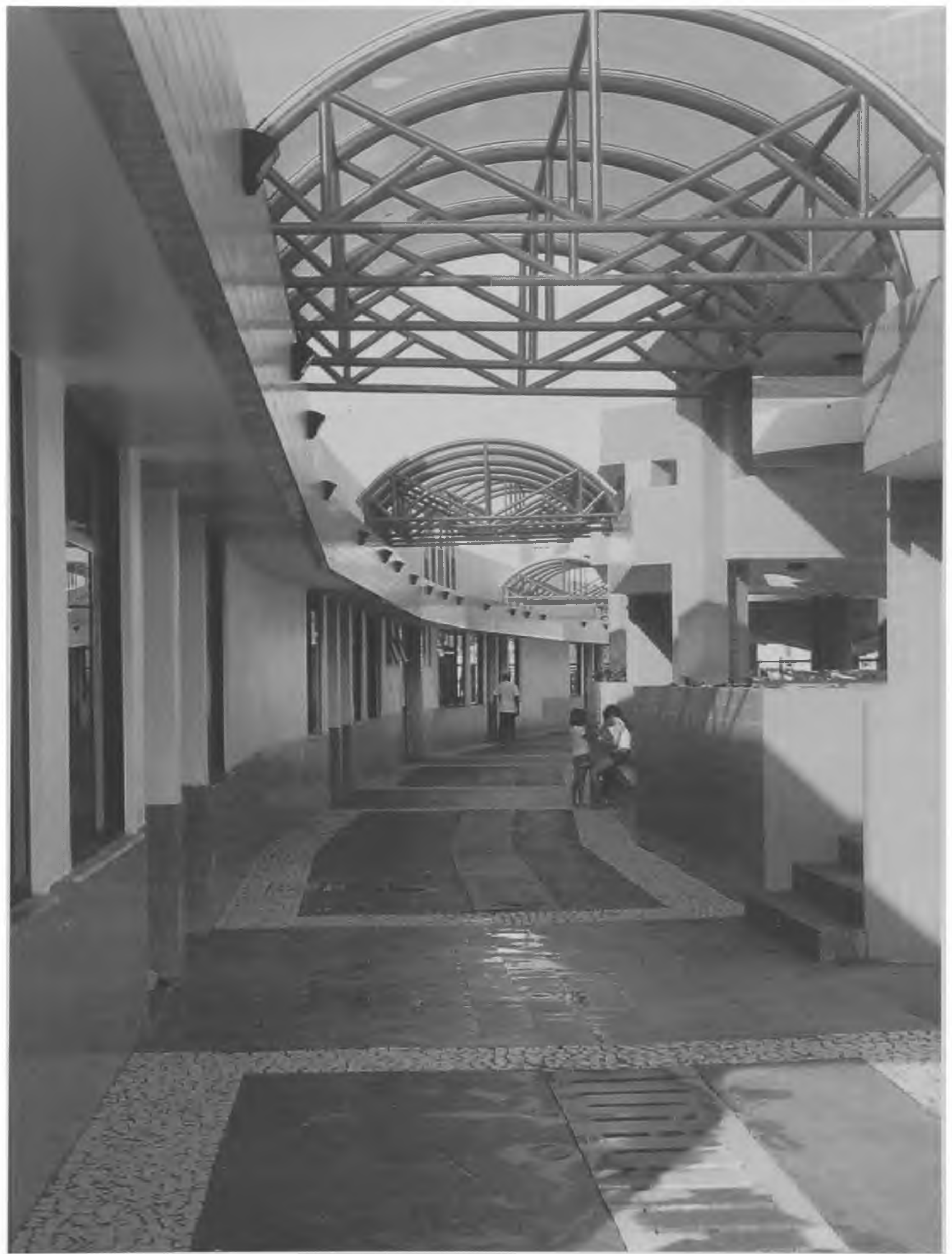

Foto 3: Acesso aos restaurantes, Parque Costa Azul

Foto: Angelo Serpa 


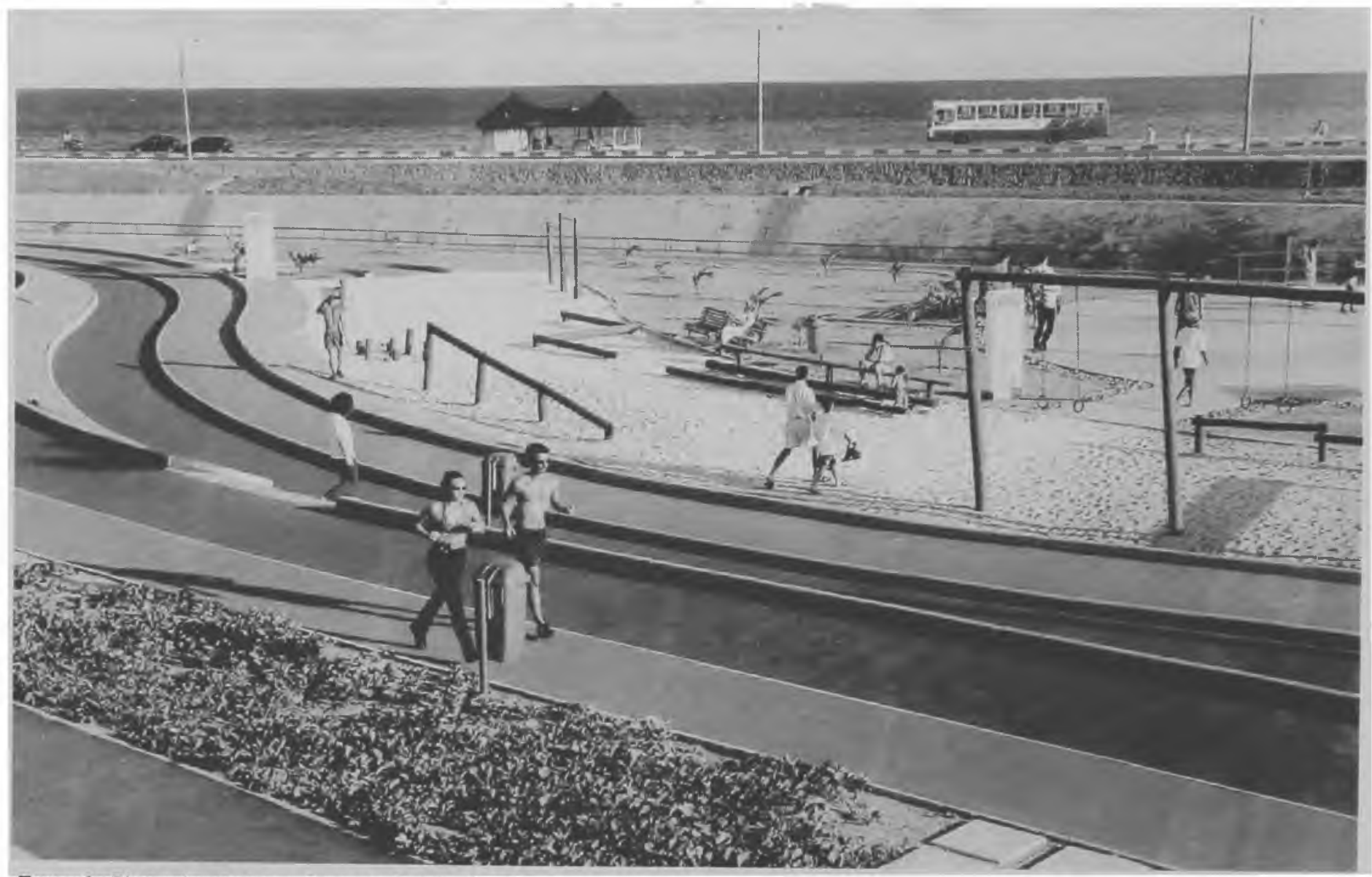

Foto 4: Pista de cooper, Parque Costa Azul

Foto: Angelo Serpa

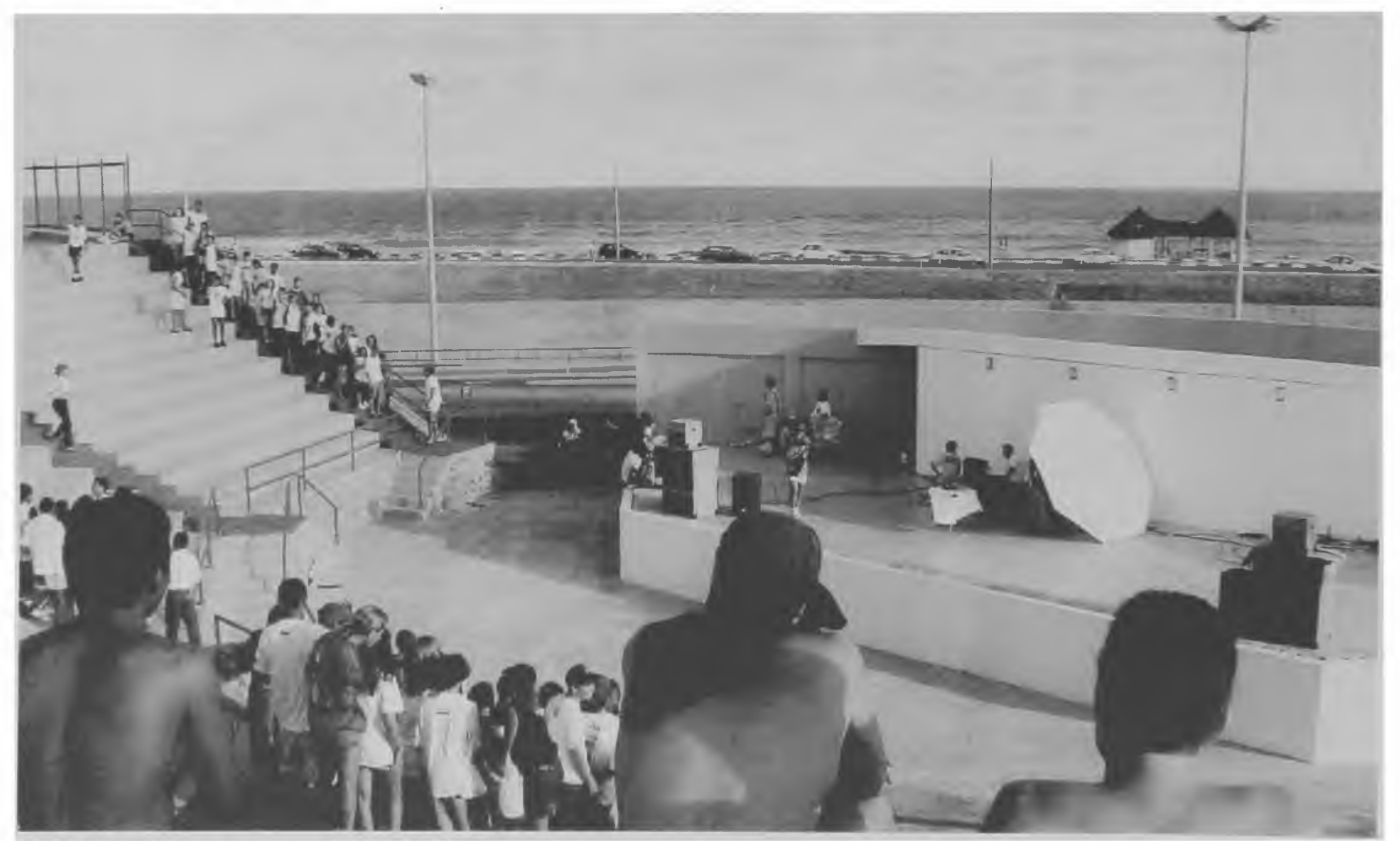

Foto 5: Anfiteatro, Parque Costa Azul

Foto: Angelo Serpa

34 Paisagem

São Paulo n. 13 p. 29 - 48 - dez. 2000

Ensaios

13 


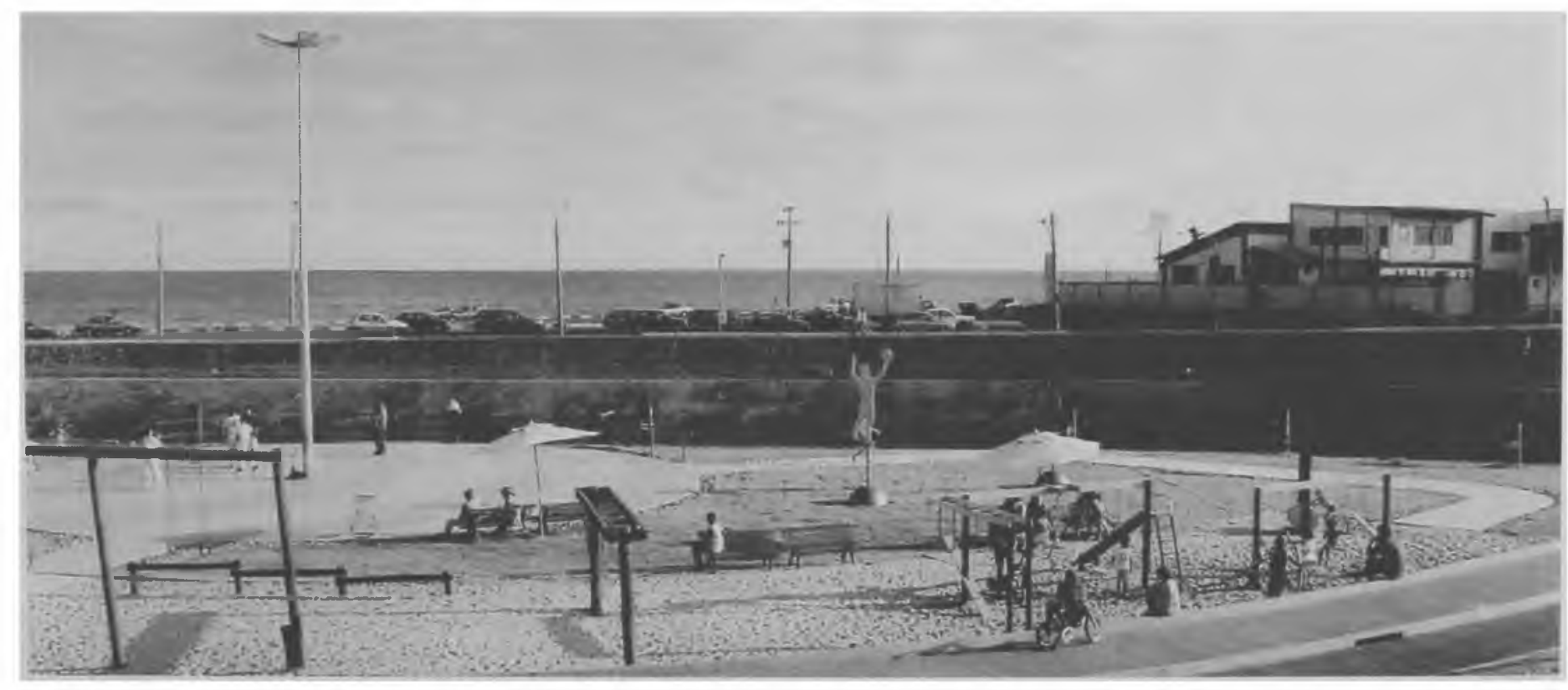

Foto 6: Equipamentos para ginástica, Parque Costa Azul

Foto: Angelo Serpa

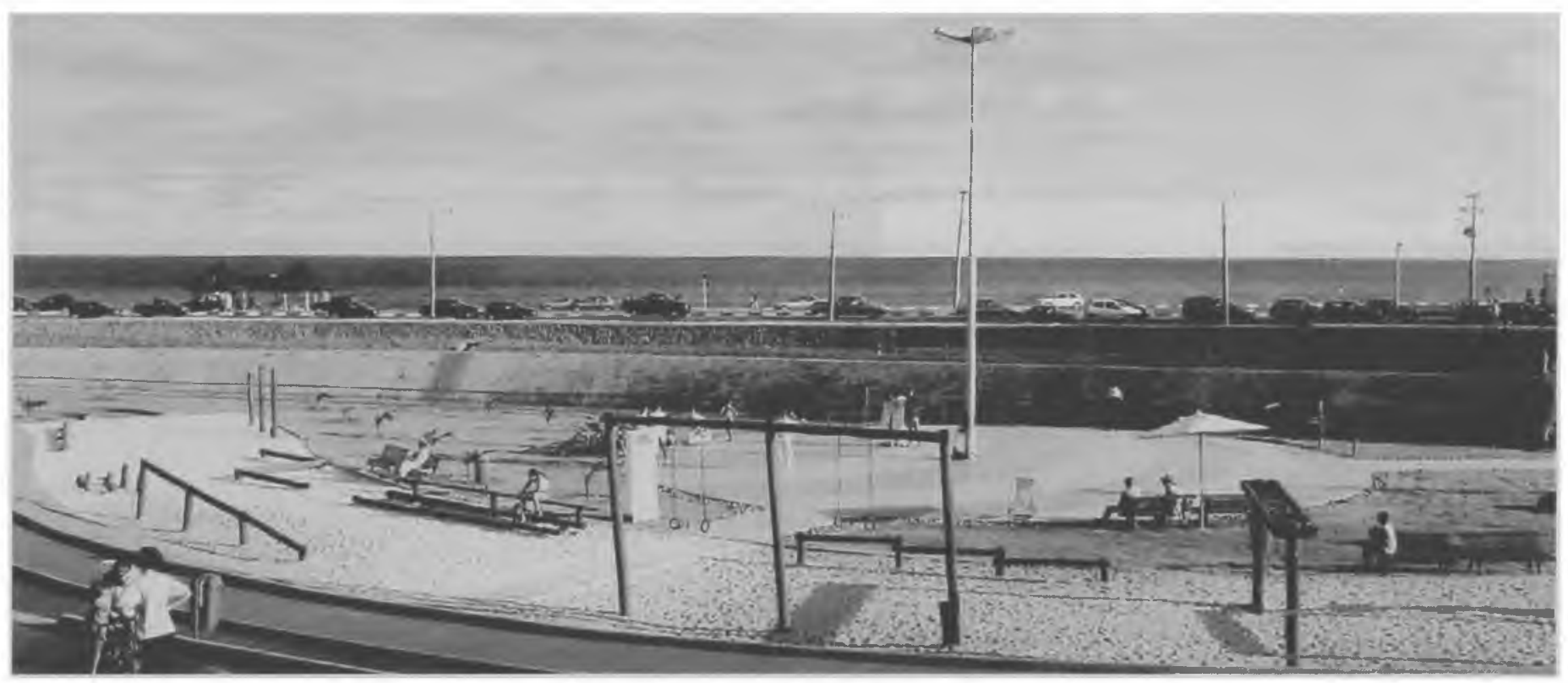

Foto 7: Equipamentos para ginástica, Parque Costa Azul

Fotos: Angelo Serpa

O projeto do Jardim dos Namorados faz parte de um amplo programa da CONDER para a orla marítima de Salvador, com ações que objetivam a recuperação ambiental, reurbanização e implantação de equipamentos de lazer. A área desempenha um importante papel na estrutura urbana em função de sua posição geográfica privilegiada, no bairro da Pituba, um dos principais vetores de expansão da cidade, com ligações que permitem sua plena articulação com a área do Iguatemi, centro de convençōes e aeroporto. Premissas para o projeto executado pela empresa Tecnosolo S/A foram a melhoria do espaço público e sua qualificação para o uso dos pedestres, a reorganização da circulação viária e a requalificação da infra-estrutura urbana (Tecnosolo, 1998). A área recebeu novos equipamentos, como ciclovias (Foto 8), quadras poliesportivas (Foto 9), quiosques (Foto 10) e playground infantil (Foto 11), com melhorias no sistema viário e de circulação e nova iluminação. 
Foto 8: Ciclovia, Jardim dos Namorados Foto: Angelo Serpa

Foto 9: Quadra

Poliesportiva, Jardim

dos Namorados

Foto: Angelo Serpa
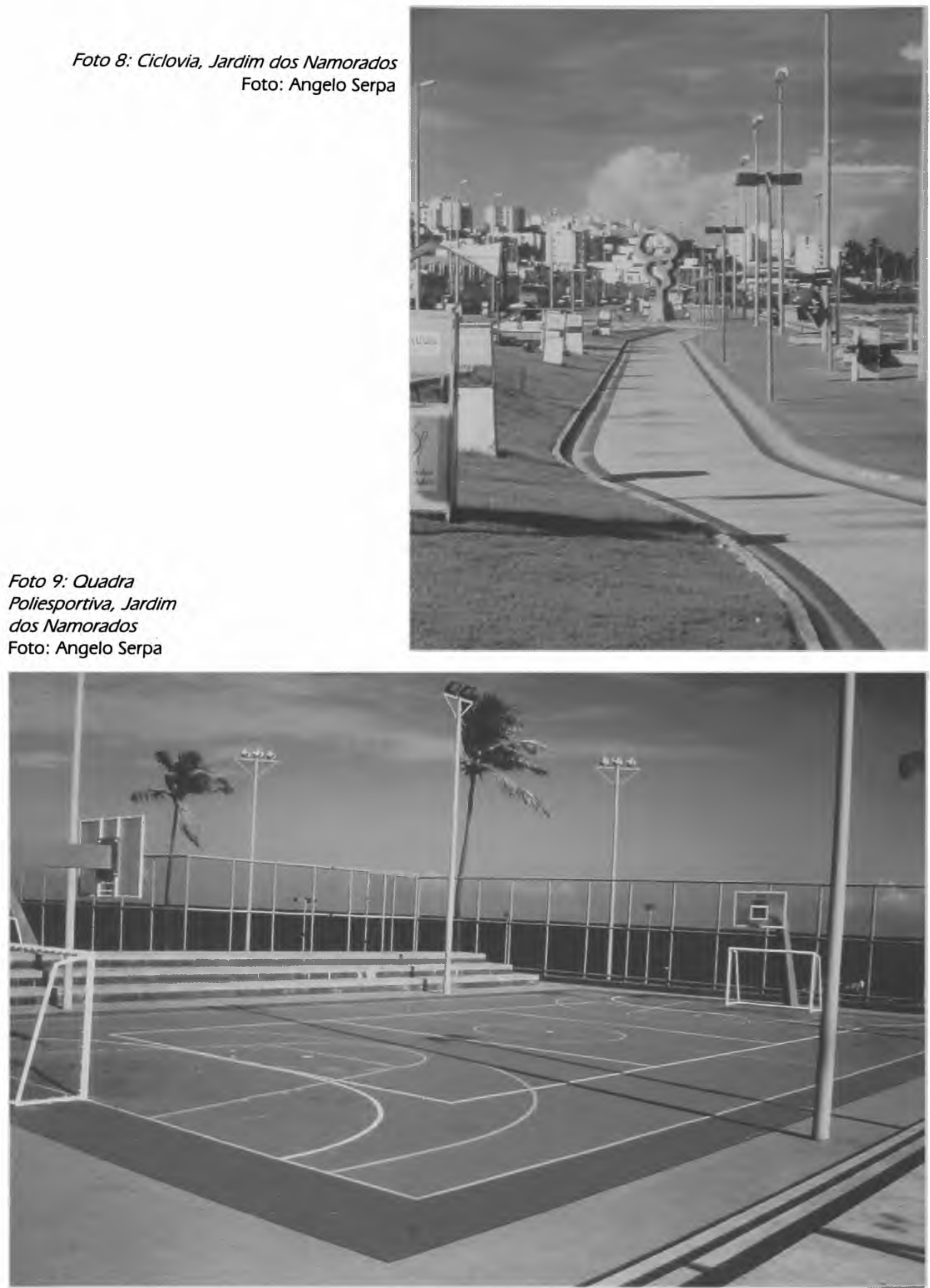

São Paulo n. 13 p. 2948 dez. 2000 
Dimensões de Performance de Projetos Paisagísticos Contemporâneos na Orla Marítima de Salvador, Bahia

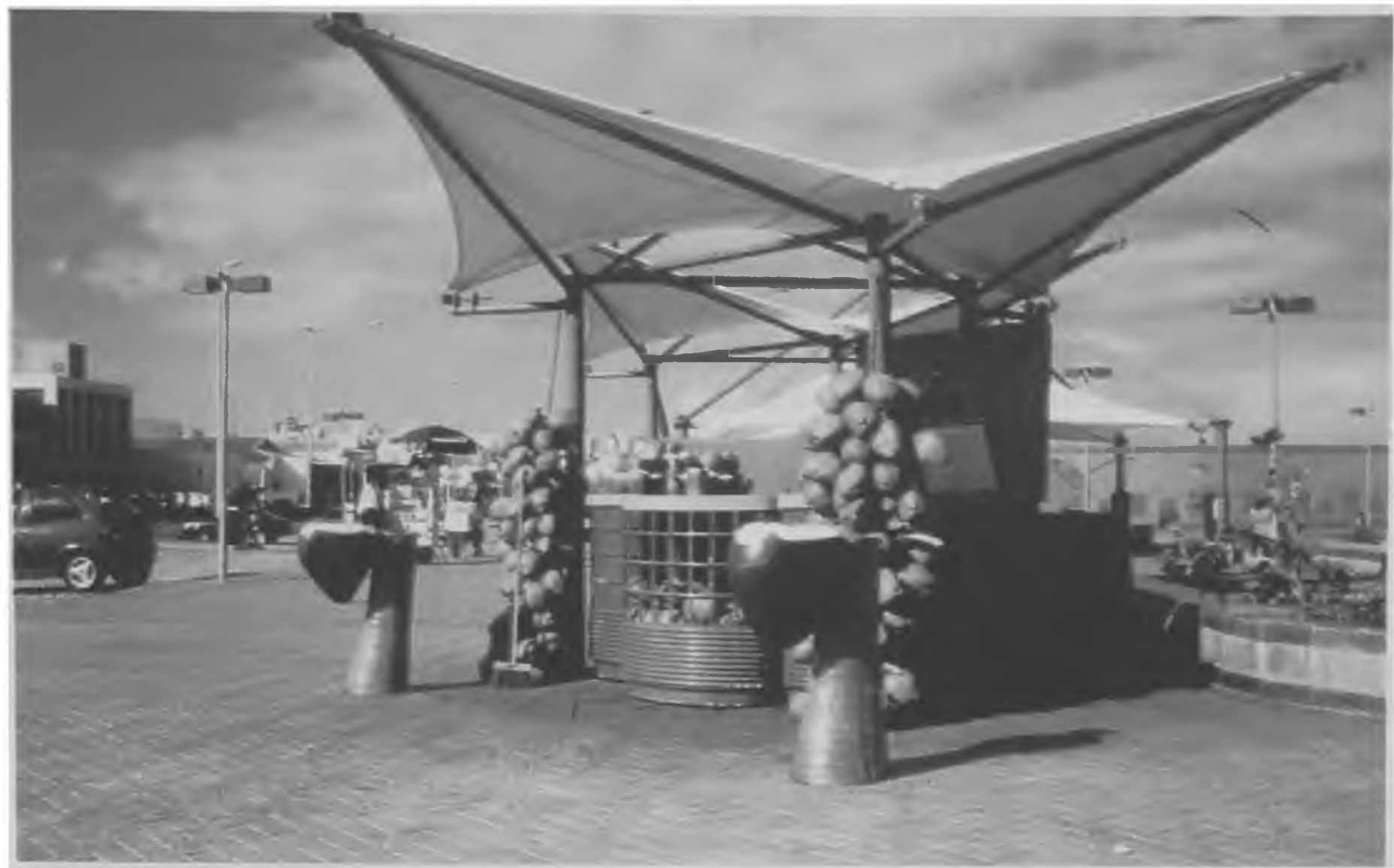

Foto 10: Quiosque, Jardim dos Namorados

Foto: Angelo Serpa

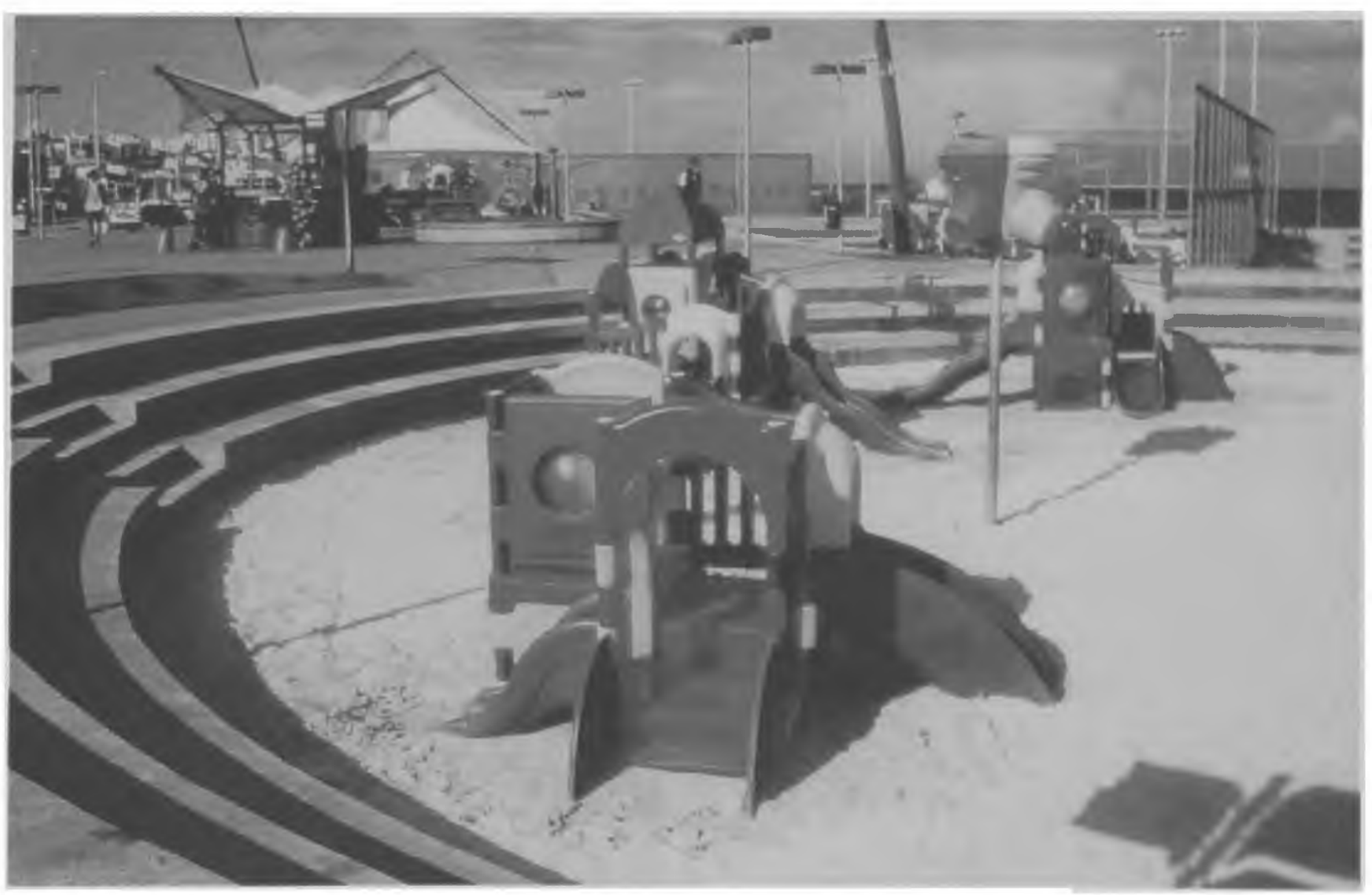

Foto 11: Playground infantil, Jardim dos Namorados

Foto: Angelo Serpa 


\section{Paisagismo Contemporãneo}

De acordo com Macedo (1999), os anos 90 marcaram o surgimento de uma nova ruptura na arquitetura paisagística brasileira, em que o "modernismo" paisagístico, predominante nos projetos dos espaços livres públicos entre as décadas de 50 e 90, "torna-se apenas uma das opçōes para a solução formal dos novos espaços que se configuram ao lado de um sem número de novas possibilidades projetuais" (Macedo, 1999). Segundo o autor, a linha projetual modernista não é totalmente abandonada, mas, pouco a pouco, vão sendo introduzidos, nos projetos, elementos impensáveis nos anos de vigência do modernismo pleno: elementos "exóticos" que passam a conviver com os elementos "modernistas", como plantas tropicais, pisos de mosaico português e ardósia, decks e pisos em toras de madeira (Macedo, 1999).

Nos dois projetos analisados no presente trabalho há evidências da utilização dessas novas linguagens projetuais identificadas por Macedo. O Parque Costa Azul e o Jardim dos Namorados são marcados pela funcionalidade dos subespaços e pela ausência de vegetação de porte, com uma forte presença de elementos construídos e de obras artísticas, como painéis e esculturas (Fotos 12, 13 e 14), de renomados artistas plásticos baianos. Pórticos coloridos (Fotos 15 e 16) e de formas diferenciadas também estão presentes, denotando a influência de projetos desenvolvidos na Europa e Estados Unidos (Macedo, 1996).

Foto 12: "O Sol de Ouro", Jardim dos Namorados Foto: Angelo Serpa

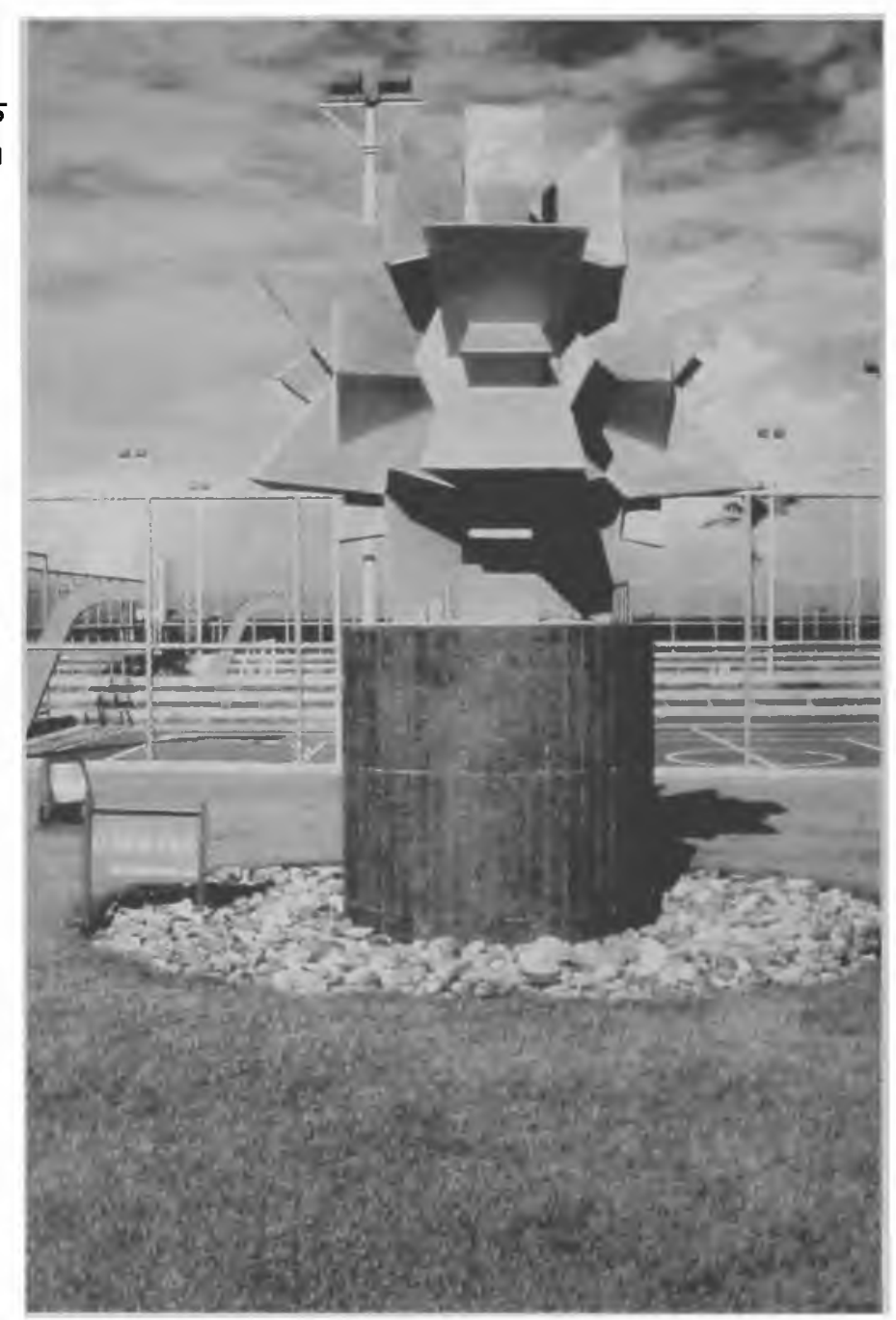




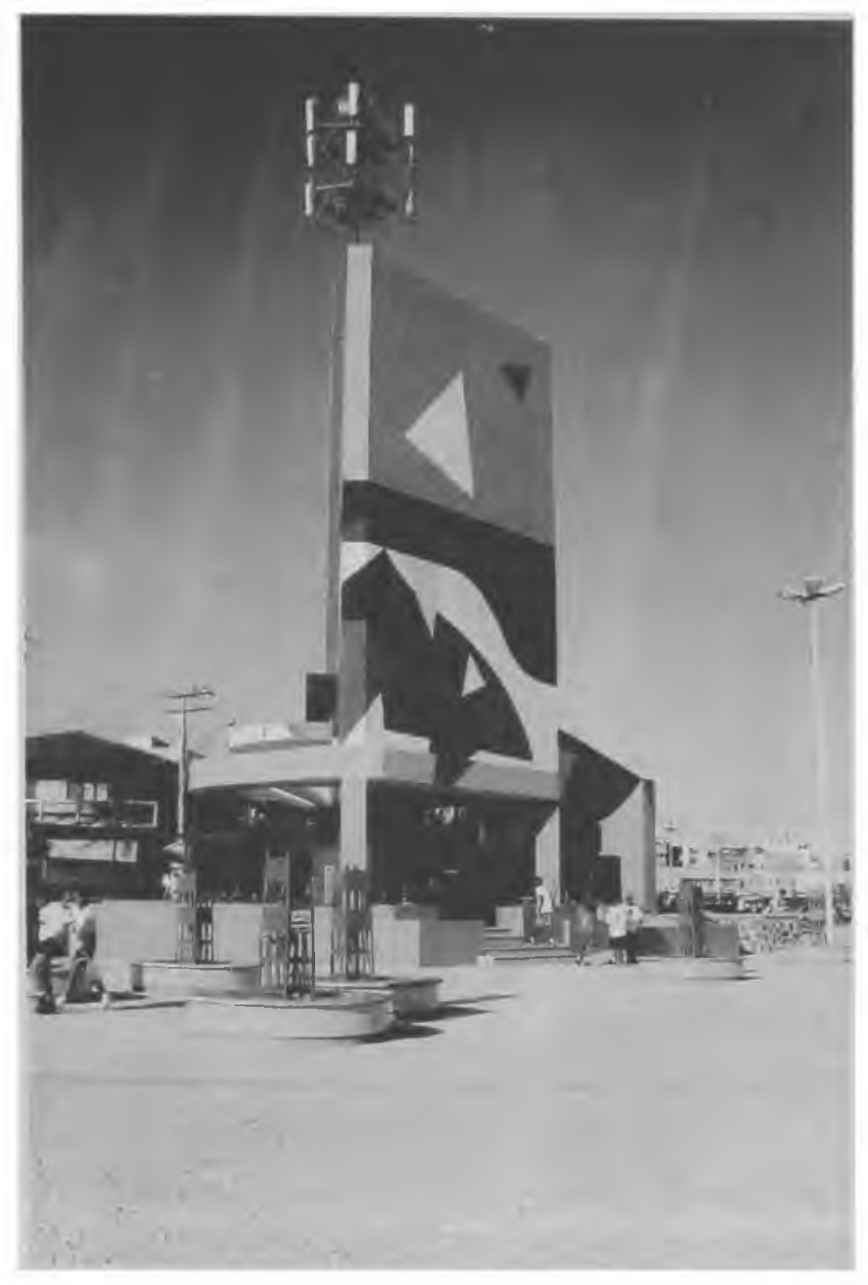

Foto 13: Painel, Parque Costa Azul

Foto: Angelo Serpa

Foto 14: Escultura, Parque Costa Azul Foto: Angelo Serpa

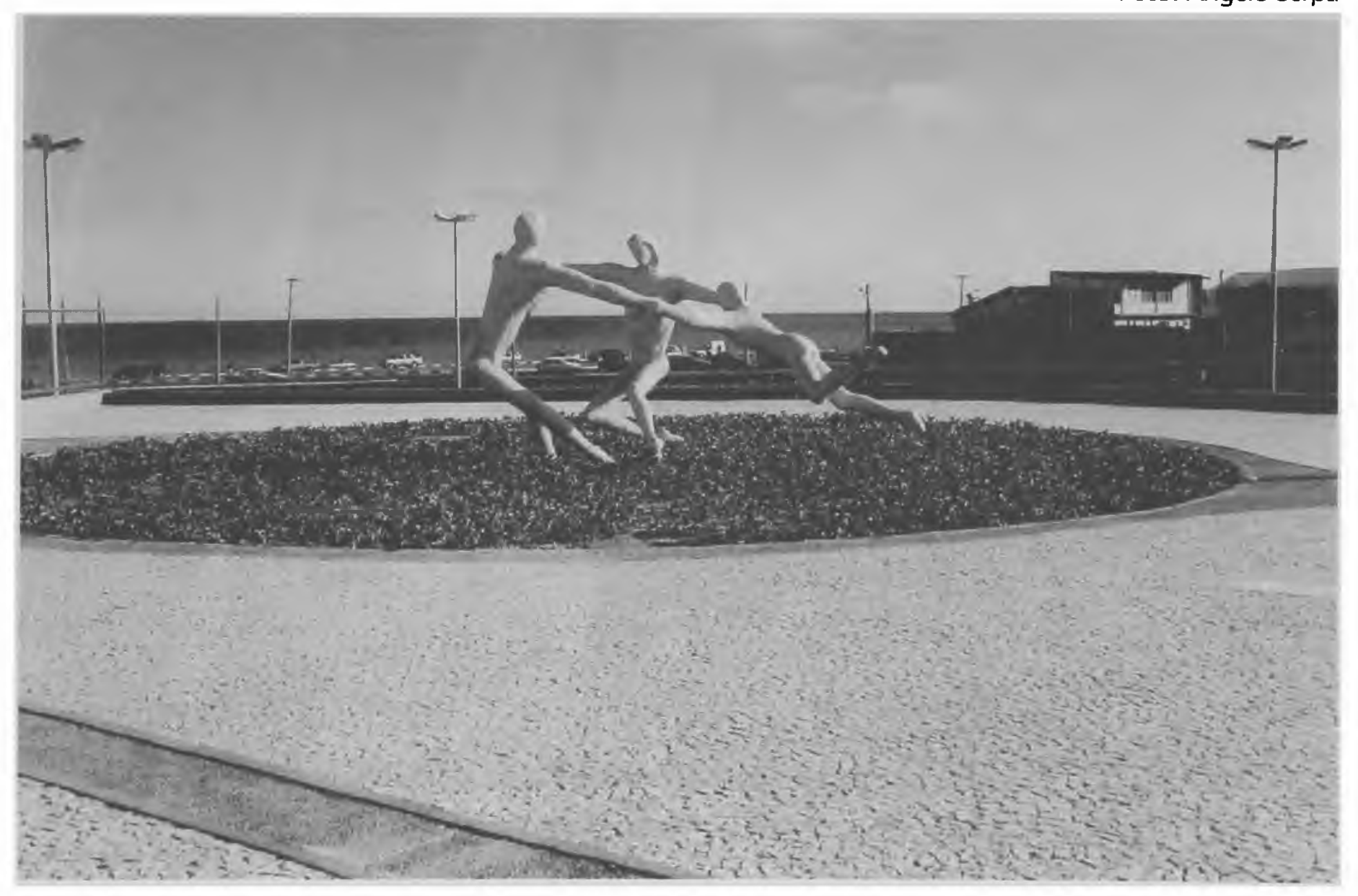

São Paulo n. 13 p. 2948 dez. 2000 

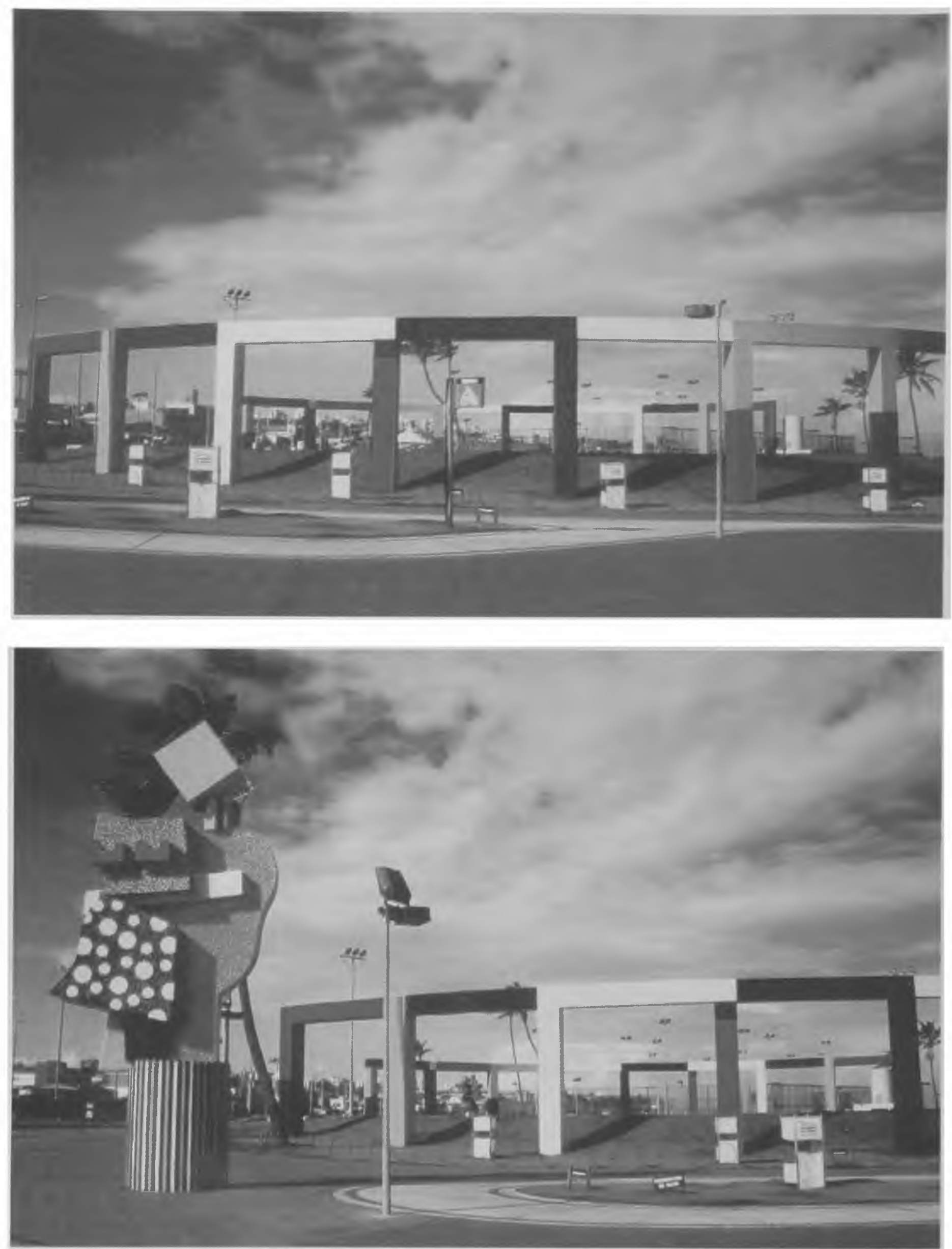

Fotos 15 e 16: Pórtico de acesso ao espaço Rosa dos Ventos, Jardim dos Namorados Fotos: Angelo Serpa

\begin{tabular}{l|l|}
40 & Paisagem \\
Ambiente \\
Ensaios \\
13
\end{tabular}


A descrição de Macedo, dos elementos presentes nos projetos em execução no Brasil, desse novo período por ele denominado de "contemporâneo", é perfeita para caracterizar tanto o Parque Costa Azul como o Jardim dos Namorados: "O pórtico, como uma releitura dos velhos arcos do triunfo e das arcadas das cidades francesas e italianas, os pisos rígidos, com desenhos geometrizados, o uso e abuso de simetrias $e$, por contraste, de assimetrias no desenho de pisos, o mobiliário urbano de desenho arrojado, a vegetação controlada e presa em eixos $e$ colunatas" (Macedo, 1999).

Áreas de grande extensão, o Parque Costa Azul e o Jardim dos Namorados são estruturados por elementos arquitetônicos e não pelos elementos de vegetação (Foto 17). Percebe-se que há uma supervalorização da adequação funcional (Fotos 18 e 19) e estética dos subespaços, em detrimento de sua adequacão ambiental (Macedo, 1995): "o uso intencional de vegetação, necessário para minimizar os efeitos da forte radiação solar em praticamente todo o país, é muitas vezes reduzido, de modo a se conseguir os efeitos cênicos desejados" (Macedo, 1999).

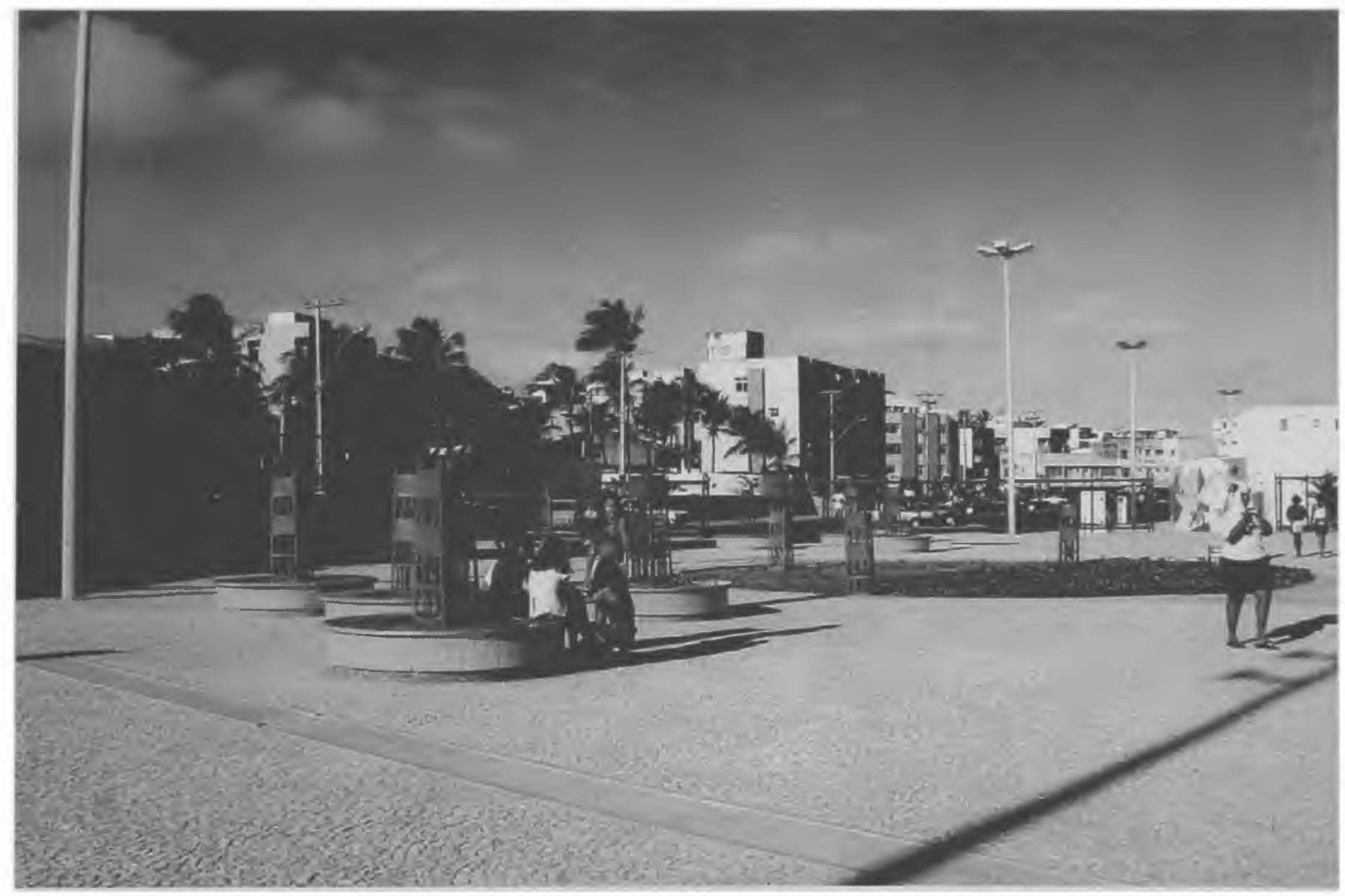

Foto 17: Vegetação incipiente e confinada em canteiros, Parque Costa Azul Foto Angelo Serpa 


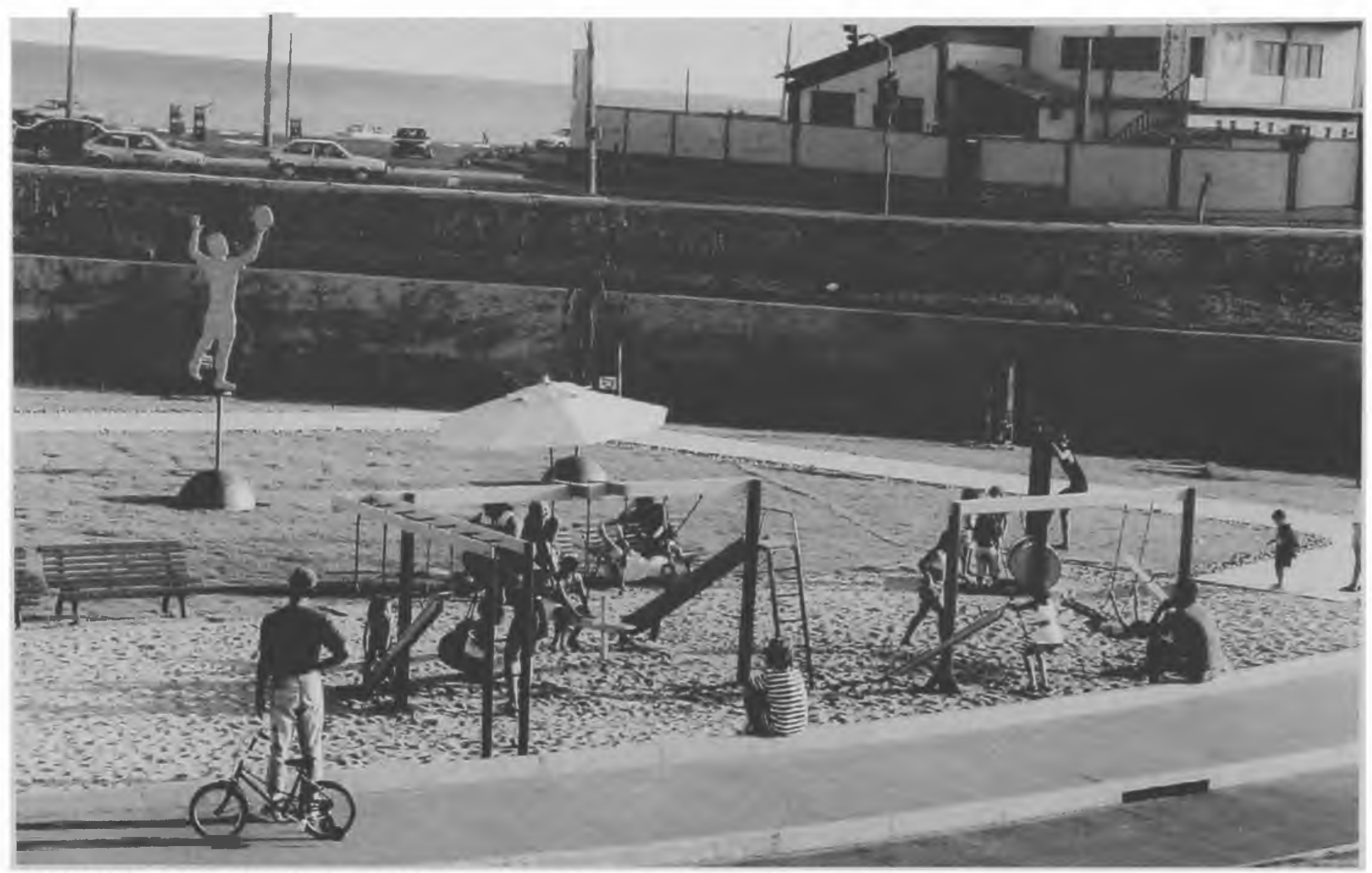

Foto 18: Funcionalidade: playground e pista de cooper, Parque Costa Azul

Foto: Angelo Serpa

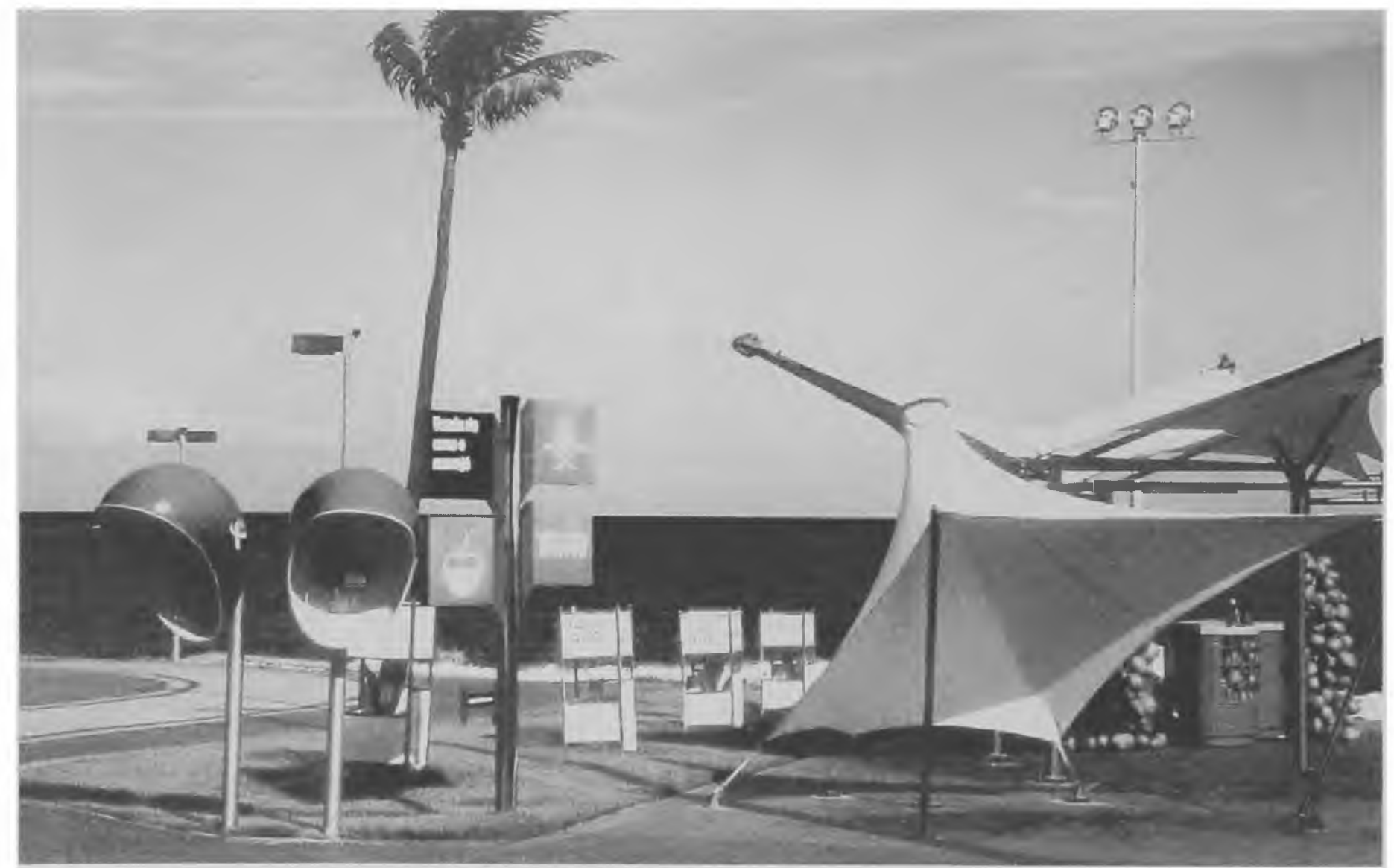

Foto 19: Cadê a vegetação? (Jardim dos Namorados) Foto: Angelo Serpa

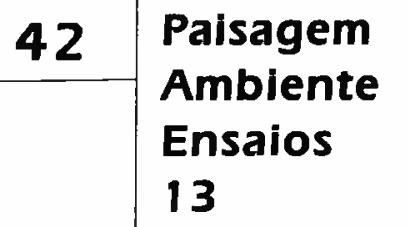

São Paulo n. 13 p. $29 \quad 48$ dez. 2000 
Embora haja a preocupação explícita com o uso de "formaçōes vegetais autóctones" (vegetação de restinga), no memorial descritivo do projeto de paisagismo do Jardim dos Namorados, onde foi privilegiado o uso de espécies da família das anarcadiáceas, malpighiaceas, nyctaginaceas, myrtaxeas, palmáceas, bromeliáceas, dentre outras, o efeito atual dos elementos vegetais é desolador. Nāo há sombra para os usuários, o que prejudica sobremaneira a apropriação da área, que acaba se restringindo aos horários de insolação menos intensa. $A$ constante necessidade de reposição da vegetação, praticamente restrita a canteiros e floreiras, mostra que o problema não é só uma questão de esperar a vegetação "crescer"

\section{Dimensóes de Performance}

A análise dos projetos selecionados baseou-se em linhas gerais nas "dimensões de performance" propostas por Kevin Lynch (1981) em sua "teoria para a boa forma urbana"(de acordo com del Rio, 1990):

vitalidade: grau em que a forma apóia as funções humanas vitais; dimensão ligada diretamente a nosso bem-estar físico;

senso: grau em que o assentamento é percebido, compreendido e estruturado mentalmente em termos espaciais e temporais;

congruência: capacidade da forma e dos espaços apoiarem ações, comportamentos e atividades sociais e humanas;

acesso: possibilidade de alcançar outras pessoas e todos os lugares do assentamento;

controle: grau em que os habitantes controlam a produção, o uso e a gerência do ambiente urbano;

eficiência: relação custo-benefício de criar e manter o assentamento;

justiça: forma pela qual os benefícios ambientais são distribuídos pela população.

Vitalidade: Pode-se dizer que ambos os projetos privilegiam o lazer ativo, em detrimento do lazer contemplativo. Deste modo, há uma predominância de formas/elementos que sugerem uma apropriação "ativa" por parte da população. Praticar esportes, "brincar", assistir um show ou mesmo almoçar nos restaurantes, parecem ser as atividades que determinam a apropriação, tanto do Jardim dos Namorados como do Parque Costa Azul. São, sem sombra de dúvida, "espaços vivos", que bem refletem as necessidades atuais de lazer da população soteropolitana. A ausência de vegetação, no entanto, pode dificultar a apropriação dos equipamentos de lazer em determinadas horas do dia, quando a insolação é intensa. 
Senso: Os assentamentos são fragmentados, fortemente segregados nas suas subunidades, o que pode dificultar a percepção e a estruturação dos espaços como um todo. A forte funcionalidade dos subespaços pode acentuar essa dificuldade, prejudicando, inclusive, as relações de identidade com o Parque Costa Azul e o Jardim dos Namorados, e, por conseguinte, sua apropriação enquanto "lugar" É possível que cada grupo de usuários se identifique mais fortemente com determinados subespaços, em detrimento de outros, não reconhecendo a "unidade" das duas áreas.

Congruência: Há, sem dúvida, uma priorização de determinados comportamentos e açōes, conforme as observações anteriores. Portanto, as formas e os espaços são capazes de apoiar ações, atividades e comportamentos relacionados com a prática do lazer ativo, mas apóiam com dificuldade açōes, atividades e comportamentos relacionados com o lazer contemplativo (no Projeto do Jardim dos Namorados há um terraço à beira-mar que pode servir para tal finalidade).

Acesso: São boas as condições de acessibilidade para automóveis, embora se detecte alguns problemas quanto ao acesso de pedestres e ciclistas. No Jardim dos Namorados, o sistema viário apresenta uma pista de acesso local, de mão única e com traçado sinuoso, com pavimento em paralelepípedos, possibilitando um acesso controlado da área interna do parque, definindo uma faixa "verde" entre essa e a pista principal. Utilizando a extensão da borda da pista e os caminhos naturais já existentes no interior do parque, foi implantado um circuito para uso exclusivo dos ciclistas, independente e destacado do calçadão para pedestres. A ciclovia é, no entanto, interrompida abruptamente na altura da passarela de acesso ao Parque Costa Azul, do outro lado da avenida, dificultando o acesso dos ciclistas a outras áreas da orla, como o Jardim de Allah e o Parque do Aeroclube. Além da passarela sobre a avenida Otávio Mangabeira, ligando a ciclovia da orla ao Parque Costa Azul, foi construída também uma ponte para pedestres de 35 metros sobre o rio Camurujipe, interligando o Costa Azul com a avenida Magalhães Neto, para facilitar o acesso dos moradores dessas áreas. O tráfego intenso de automóveis é, porém, um forte obstáculo para quem quer acessar as duas áreas de lazer a pé.

Controle e Eficiência: As duas áreas de lazer são administradas e mantidas pela CONDER, órgão ligado à administração estadual. Não há participação dos moradores das áreas próximas na gestão e manutenção do Parque Costa Azul e do Jardim dos Namorados. Há necessidade de reposição constante da vegetação dos canteiros e floreiras para ambas as áreas, custo que em parte é compensado pela existência de um mini-horto no Parque Costa Azul, que também "abastece" de mudas o Jardim dos Namorados. De modo geral, pode-se dizer que os equipamentos e materiais implantados/utilizados são de fácil manutenção e conservação.

Justiça: As duas áreas atendem fundamentalmente moradores dos bairros do Costa Azul, Pituba, Caminho das Árvores, Jardim de Allah (bairros de classe média) e freqüentadores da orla atlântica. Mas na verdade, são duas as "orlas" de Salvador. A cidade, que cresceu de sul para norte, desenvolveu-se inicialmente a partir da entrada da Baía de Todos os Santos, ao longo de sua borda leste. A dinâmica da expansão urbana permite individualizar dois vetores principais 
de crescimento. Um primeiro vetor, ao longo da BR-324, engloba uma mancha urbana de baixa renda, que pressiona os ambientes estuarinos da Baía de Todos os Santos. O segundo vetor se desenvolve ao longo da avenida Paralela, englobando uma mancha urbana de renda média alta, compreendida entre esta via e a orla atlântica. Enquanto na orla atlântica investimentos em infra-estrutura estão na ordem do dia, nas praias da baía a situação é de abandono e degradação. Em uma cidade, em que grande parte da população anda a pé, por falta de recursos para utilizar o transporte público, não é difícil perceber para que perfil de usuário foram pensados o Parque Costa Azul e o Jardim dos Namorados.

\section{IDENTIDAde e “Lugar"}

O antropólogo francês Marc Augê ensina que se um lugar pode se definir como histórico, relacional e identitário, um espaço que não se pode definir nem como identitário, nem como relacionai, nem como histórico, deve ser encarado então como um não-lugar. Augê defende a tese de que a supermodernidade é produtora de não-lugares: um mundo onde se desenvolve uma rede cerrada de transportes e máquinas automáticas; um mundo prometido à individualidade solitária, ao provisório e ao efêmero (Augê, 1994).

Na velha capital baiana os sinais dessa supermodernidade de Augê convivem lado a lado com problemas estruturais crônicos: desemprego, miséria, serviços precários de saúde e escolas públicas decadentes "contrabalançados" por cenários artificialmente construídos, sem relação com o entorno, de nulo conteúdo histórico, mas "alimentados" por uma classe média ávida por consumo e lazer. Espaços sem identidade e conteúdo histórico, os não-lugares baianos poderiam estar em qualquer lugar-novos projetos acrescentados ao tecido urbano tradicional, repleto de antigos lugares, que a supermodernidade do marketing turístico promove a "lugares de memória" (Serpa, 1999a).

Os novos parques da orla soteropolitana carregam também as marcas da supermodernidade de que fala Augê: incentivo ao consumo e ao lazer ativo, "cenarização" do espaço livre público, fragmentação em subespaços funcionais, uso de formas "exóticas" e de cores vivas. Paisagens de lazer com múltiplas atrações, que combinam artigos de consumo, atrações "naturais". estátuas/figuras, jogos, "aventura", prática de esportes, restaurantes e vegetação. A ordem é "encenar" e "simular" o mundo real, tornando-o mais acessível e seguro aos seus usuários (Serpa, 1999b).

Não que não haja tentativas de buscar identidade com os futuros usuários dos projetos executados. A implantação do espaço multiuso "Rosa dos Ventos" no Jardim dos Namorados, com fileiras de arquibancadas paisagisticamente modeladas no terreno e iluminação especial, é um bom exemplo disso. Considerado como marco referencial do parque, o "Rosa dos Ventos" deverá servir, de acordo com o memorial descritivo do projeto, como "espaço aberto de convivência, atendendo a pequenos eventos para adultos e crianças e para a prática esportiva das academias e grupos de ginástica lapresentação de 'rodas de capoeira', escolas de dança, ioga, tai chi chuan, artes marciais, etc.)" Desse modo, foi mantida a marca da rosa dos ventos 
no piso, porém com uma nova linguagem em termos de pavimento, transformando o espaço outrora usado para aeromodelismo, controlado por cabo, em um minianfiteatro natural (Tecnosolo, 1998).

A apropriação tímida do espaço "Rosa dos Ventos" (Foto 20) parece não confirmar os desejos expressos no memorial descritivo do projeto. Talvez seja cedo para a apropriação do "Rosa dos Ventos" enquanto "lugar" mas a possibilidade de desenvolvimento de relaçōes de identidade com o espaço não pode ser de todo descartada. De acordo com Augê (1994), existe evidentemente o não-lugar como o lugar: ele nunca existe sob uma forma pura; lugares se recompóem nele; relações se reconstituem nele. O lugar e o não-lugar são, antes, polaridades fugidias: o primeiro nunca é completamente apagado e o segundo nunca se realiza totalmente. Para Relph (1979), "lugar" significa muito mais que o sentido geográfico de localização. Não se refere a objetos e atributos das localizações, mas ao tipo de experiência e envolvimento com o mundo, à necessidade de raízes e de segurança.

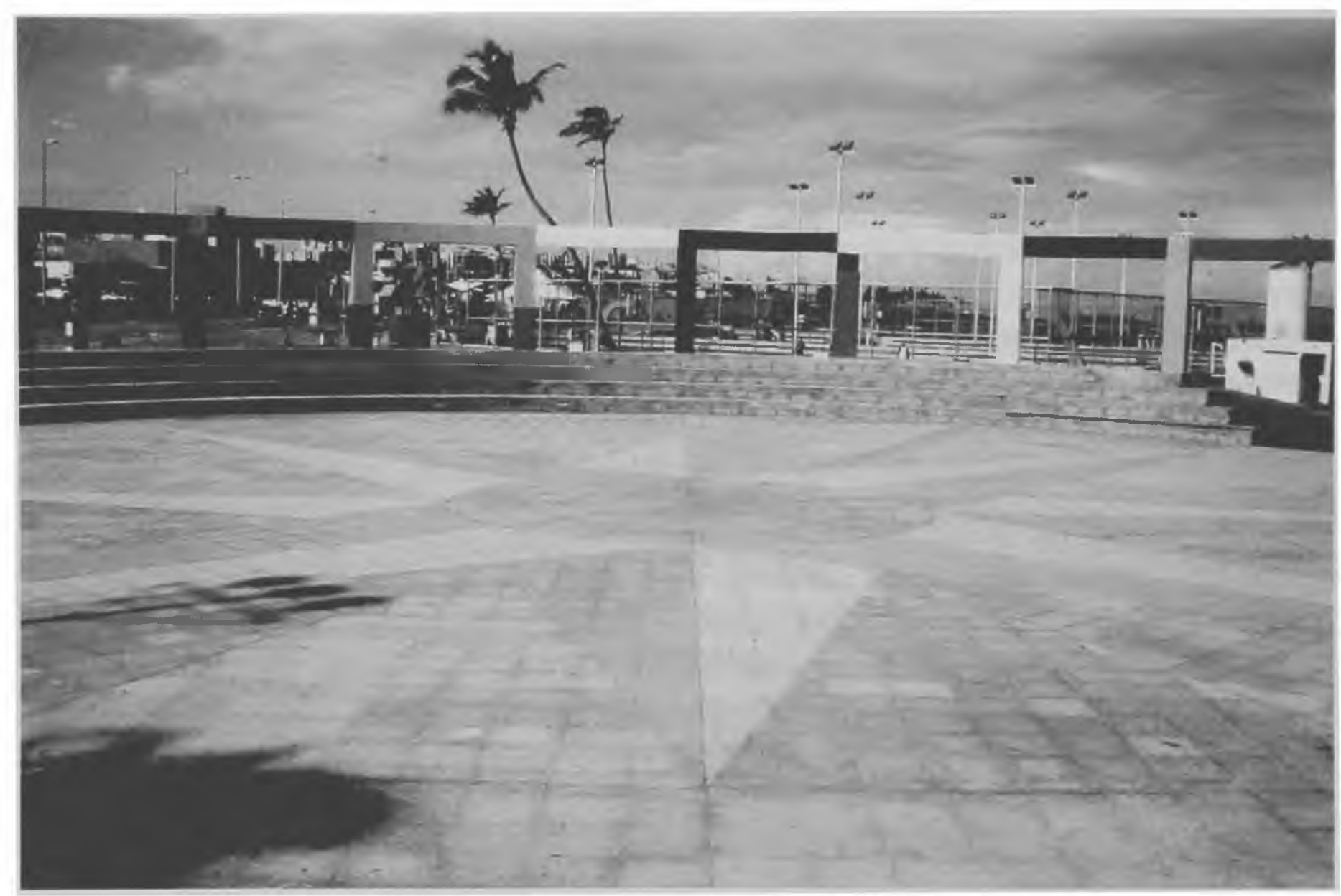

Foto 20: Espaço Rosa dos Ventos, Jardim dos Namorados Foto: Angelo Serpa

\section{Conclusōes}

A análise das dimensões de performance do Parque Costa Azul e Jardim dos Namorados mostra que não existem "boas formas urbanas" universais. Não se pode fugir da análise do contexto

\begin{tabular}{|l|l|}
46 & $\begin{array}{l}\text { Paisagem } \\
\text { Ambiente } \\
\text { Ensaios } \\
13\end{array}$ \\
\cline { 2 - 2 }
\end{tabular}

São Paulo n. 13 p. 2948 dez. 2000 
socioeconômico e político, no qual formas urbanas originam funções e estas, por sua vez, apóiam e legitimam as primeiras. O que parece fundamental na avaliação dos dois projetos é a discriminação de parte da população, que não tem possibilidade de acesso aos espaços livres públicos analisados no presente trabalho.

Das 3 milhões e 691 mil viagens feitas diariamente pelos habitantes de Salvador, 1 milhão e 70 mil são feitas a pé, de acordo com uma pesquisa coordenada por Francisco Ulisses Santos Rocha, da Superintendência de Transportes Públicos da Prefeitura Municipal. As causas apontadas pelo estudo - que contemplou 600 mil domicílios - para esse fato são, além das dificuldades financeiras (a principal), as necessidades de deslocamentos curtos, a deficiência do sistema de transportes e a tradição das caminhadas em festas populares. Apenas $21 \%$ dos domicílios pesquisados têm um carro estacionado na garagem (Jornal $A$ Tarde, 6/8/99).

Desse modo, ao priorizar a implantação de novos parques e praças na orla atlântica de Salvador, em detrimento da orla suburbana, em que a renda média da populaçāo é de 1 a 3 salários mínimos, o governo e a prefeitura acabam discriminando grande parte da população soteropolitana, justo aquela com mais dificuldades de deslocamento e falta de opções de lazer. Assim, as dimensōes de performance apontadas por Lynch (1981), em especial "acesso" e "justiça" mostram, ao se contextualizar a análise dos projetos, que as "boas formas urbanas" não são, nos dois casos analisados, "boas" para todos os soteropolitanos.

Se, por um lado, o Parque Costa Azul e o Jardim dos Namorados vão mostrar a "liberdade de criação". própria do paisagismo contemporâneo (Macedo, 1999), o que é, sem dúvida, algo bastante positivo, por outro lado, há semelhanças evidentes dos materiais e equipamentos utilizados com os de outros projetos já realizados ou em execução na capital baiana e em outras cidades do país. Empobrecimento de linguagem e repertório projetual? Homogeneização da linguagem projetual em conseqüência da globalizaçāo e da internacionalização dos projetos paisagísticos? Nunca a discussão sobre contextualizaçāo regional de projetos paisagísticos e arquitetônicos foi tão atual e necessária. Aqui, o aprofundamento da discussāo sobre identidade e lugar pode ser bastante útil e reveladora para ajudar a esclarecer a relação entre forma e a apropriação social dos espaços livres públicos no contexto brasileiro.

\section{Bibliografia}

AUGÊ, M. Não-Lugares - Introdução a uma antropologia da supermodernidade. Campinas, São Paulo: Papirus, 1994.

CONDER. Projeto Metropolitano - Investimentos urbanos na Região Metropolitana de Salvador. Salvador, 1998.

DEL RIO, V. Introdução ao desenho urbano no processo de planejamento. São Paulo: Pini Editora, 1990.

JORNAL A TARDE. Andar a pé é o segundo meio de deslocamento em Salvador. Salvador, 6 ago. 1999. p. 5.

LYNCH, K. A Theory of good city form. Cambridge (Massachussets): MIT Press, 1981

MACEDO, S. S. Espaços Livres. Paisagem e Ambiente - Ensaios. São Paulo: FAUUSP, n. 7, p. 15-56, 1995.

Quapá - Quadro do paisagismo. São Paulo: FAUUSP, 1996.

São Paulo n. 13 p. 2948 dez. 2000
Paisagem Ambiente Ensaios 
MACEDO, S. S. Ouadro de paisagismo no Brasil. São Paulo: FAUUSP, 1999.

RELPH, E. As bases fenomenológicas da geografia. Geografia, Rio Claro: Unesp, v. 4, n. 7. p. 1-25, abr. 1979 SERPA, A. Os não-lugares de Salvador. Jornal Soterópolis, Salvador, n. 9. p. 14, maio/jun., 1999.

A. Clonagem de paisagens: Como alguns projetos de intervenção transformam as paisagens urbanas em nāo-lugares. In: VASCONCELOS, P. e Silva, S. B. M. (orgs). Novos estudos de geografia urbana brasileira. Salvador, 1999. Tese (Mestrado) (Uiversidade Federal da Bahia) e EDUFBA, p. 237-244.

TECNOSOLO S/A. Orla marítima de Salvador - Parque jardim dos namorados. Projeto de recuperação ambiental $e$ urbanística. Salvador, 1998. 